\title{
Heat Emission from a Burning Cigarette*
}

\author{
by
}

\author{
K. Miura $^{1}$, A. Nagao ${ }^{1}$ and K. Ueyama ${ }^{2}$
}

${ }^{1}$ Tobacco Science Research Center, Japan Tobacco Inc., 6-2, Umegaoka, Aoba-ku, Yokohama, Kanagawa 227-8512, JAPAN

${ }^{2}$ Department of Chemical Science and Engineering, Graduate School of Engineering Science, Osaka University, 1-3

Machikaneyama-cho, Toyonaka, Osaka 560-8531 JAPAN

\section{SUMMARY}

We investigated the relationship between the smoldering burn rate and the heat transfer from a burning cigarette by measuring the heat emitted by radiation and convection, separately. The net heat generated and the net heat emitted by a burning cigarette did not vary with a change of the cigarette smoldering burn rate. The total heat emitted from a statically burning cigarette was about $50 \%$ of the total combustion heat. About $50 \%$ of the heat emitted was released as radiation heat. The smoldering burn rate did not affect the total amount of heat emitted nor the ratio of radiated heat to convected heat. [Beitr. Tabakforsch. Int. 19 (2001) 245-50]

\section{ZUSAMMENFASSUNG}

Es wurde die Beziehung zwischen der Glimmgeschwindigkeit und dem Wärmetransfer einer brennenden Cigarette untersucht, indem Wärme- und Konvektionsstrahlung getrennt gemessen wurden. Die produzierte Nettowärme und die von einer brennenden Cigarette ausgestrahlte Nettowärme änderten sich bei veränderter Abbrenngeschwindigkeit der Cigarette nicht. Die gesamte Wärme, die von einer statisch brennenden Cigarette emittiert wurde, betrug 50\% der gesamten Verbrennungswärme. Ungefähr 50\% der ausgestrahlten Wärme wurde als Strahlungswärme abgegeben. Die Glimmgeschwindigkeit hatte weder Einfluß auf die Gesamtheit der Wärmeemission noch auf das Verhältnis zwischen Strahlungswärme und Konvektionswärme. [Beitr. Tabakforsch. Int. 19 (2001) 245-50]

\section{RESUME}

La relation entre le taux de combustion et le transfert de la chaleur d'une cigarette en combustion a été examiné en mesurant séparément la chaleur émise par rayonnement et celle émise par convection. La chaleur nette dégagée et la chaleur nette émise par une cigarette en combustion n'a pas varié après un changement de la vitesse de combustion. La chaleur totale émise par une cigarette en combustion statique est d'environ $50 \%$ de la chaleur totale de combustion. Cinquante pourcent environ de la chaleur émise est dégagée par rayonnement. Le taux de combustion n'a pas affecté ni la quantité totale de la chaleur émise ni le rapport entre la chaleur émise par rayonnement et celle émise par convection. [Beitr. Tabakforsch. Int. 19 (2001) 245-50]

\section{INTRODUCTION}

A cigarette burning rate is affected by various parameters: oxygen concentration, temperature, the reaction rate of tobacco shreds and so on. It is important to clarify the mechanism of cigarette burning in order to specify the rate-determining factor. RICE reported that the static burn rate of a cigarette depended on cigarette paper variations (1). We showed that the oxygen transfer rate across a natural cigarette paper did not affect the static burning rate of the cigarette, by measuring the oxygen diffusion coefficient (2). Therefore, the heat transfer should play a key role in the burning of a cigarette.

There are few reports referring to heat transfer during cigarette burning. GUGAN measured the heat of combus- 
Table 1.

Characteristics of sample cigarettes (cigarette circumference $=25 \mathrm{~mm}$ )

\begin{tabular}{l|c|c|c|c|c|c|c|c|c}
\hline Parameters measured & A-H & A & A-L & B-H & B & B-L & C-H & C & C-L \\
\hline Tobacco density $\left(\mathrm{mg} / \mathrm{cm}^{3}\right)$ & 250 & 233 & 216 & 250 & 233 & 216 & 250 & 233 & 216 \\
Static burn rate $(\mathrm{mm} / \mathrm{min})$ & 4.7 & 5.1 & 5.7 & 5.3 & 5.7 & 6.1 & 6.5 & 7.3 & 7.5 \\
\hline
\end{tabular}

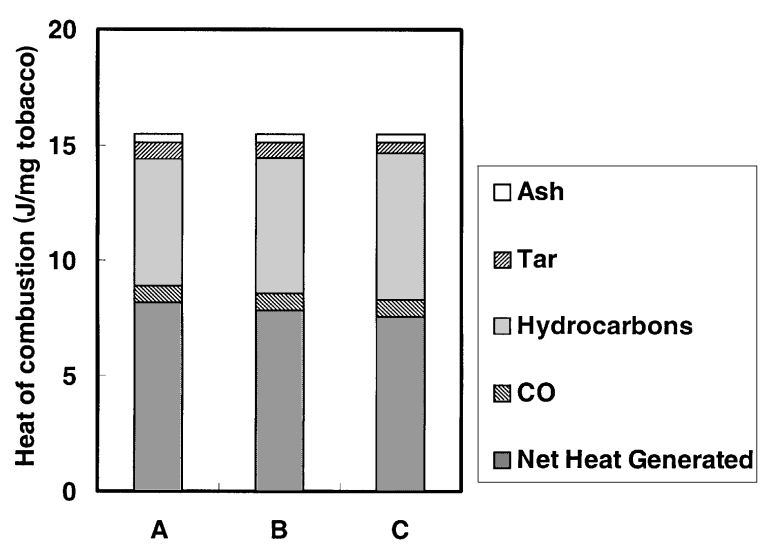

Figure 1.

Net heat generated and heat of byproducts combustion emitted from the statically burning cigarette

tion of a cigarette with a Bomb calorimeter and determined a value of $15.9 \mathrm{~J} / \mathrm{mg}$ (3). This value represents the heat generated during complete combustion of a cigarette. MURAMATSU estimated the total evolved heat of oxidation reaction to be $5.9 \mathrm{~J} / \mathrm{mg}$ from the net formation rate of carbon oxides and water (4). WAYMACK et al. determined that the net heat output of a burning cigarette is $7.5 \mathrm{~J} / \mathrm{mg}$ (5). They reported that the net heat output rate and oxygen consumption rate are proportional to the mass burning rate of a cigarette.

In this study, we tried to measure the influence of heat transfer on the static burning rate of a cigarette. The net heat generated of a burning cigarette was deduced by subtracting the enthalpy of byproducts from the total enthalpy of the cigarette. Then, the heat transfer of the heat generated was estimated by measuring heat emitted by radiation and convection, individually.

\section{HEAT GENERATION}

The net heat generated of the cigarette was estimated by the following procedure. The heat of complete tobacco combustion $\left(H_{\mathrm{cc}}\right)$ was determined to be $15.5 \mathrm{~J} / \mathrm{mg}$ from data which MURAMATSU measured with a Bomb calorimeter (4). The release of carbon monoxide (CO), total hydrocarbons, ash and dry total particulate matter ("tar") was measured during static burning, and the heat of combustion of those byproducts $\left(H_{\mathrm{bp}}\right)$ was calculated.
Cigarettes were placed vertically at the center of a $80-$ $\mathrm{mm}$ diameter tube and burned. Air flow velocity inside the tube was $33 \mathrm{~mm} / \mathrm{s}$, and the exhaust gas concentration of $\mathrm{CO}$ and hydrocarbons were measured with an infrared gas analyzer and a flame ionization detector (FID), respectively. "Tar" was collected on a Cambridge filter pad. Total hydrocarbons were converted to their propane equivalent. The heats of combustion of "tar" and ash were estimated by approximation from their elemental content to be 31.4 and $3.9 \mathrm{~J} / \mathrm{mg}$, respectively. The net heat generated was obtained by subtracting $H_{\mathrm{bp}}$ from $H_{\mathrm{cc}}$. Table 1 shows the smoldering burn rate of the sample cigarettes. The codes A-H, A, A-L, B-H, B, B-L, C-H, C, $\mathrm{C}-\mathrm{L}$ are used to represent each cigarette. Only the cigarette paper was changed for A, B, and C. Figure 1 shows the heat balance of the statically burning cigarettes. The net heat generated was about $7.8 \mathrm{~J} / \mathrm{mg}$ and did not depend on the smoldering burn rate. Incomplete cigarette combustion could be verified from the byproducts formation. The ratio of incomplete combustion to complete combustion $\left(1-H_{\mathrm{bp}} / H_{\mathrm{cc}}\right)$ was approximately constant at 0.5 , regardless of the smoldering burn rate.

\section{HEAT EMISSION}

The total heat emitted by radiation and convection was estimated as follows. Figure 2 shows a schematic diagram of the experimental apparatus used to measure the total heat emitted from a burning cigarette. Heat flux sensors (Vatell Corporation) are mounted on the wall and the ceiling plate, both made from copper. Each sensor is 50 $\mathrm{mm}$ square, and can measure average heat flux. Emissivity of each heat flux sensor surface is about 1 , and the copper plate temperature is maintained at about $22{ }^{\circ} \mathrm{C}$ with cooling water. Each side wall is covered with 4 heat flux sensors, and 9 heat flux sensors are used for the ceiling. The cigarette is placed in the vertical direction at a point $50 \mathrm{~mm}$ from the ceiling, and burned in the ambient atmosphere. The wall heat flux sensors can detect mainly the total emitted heat radiated from the cigarette's surface, and the ceiling heat flux sensors can detect preferentially the total emitted heat by convection.

The influence of convected heat on wall sensors and radiated heat on ceiling sensors was estimated. The temperature at a point $20 \mathrm{~mm}$ from the surface of a burning cigarette was measured with a bare platinum/ 


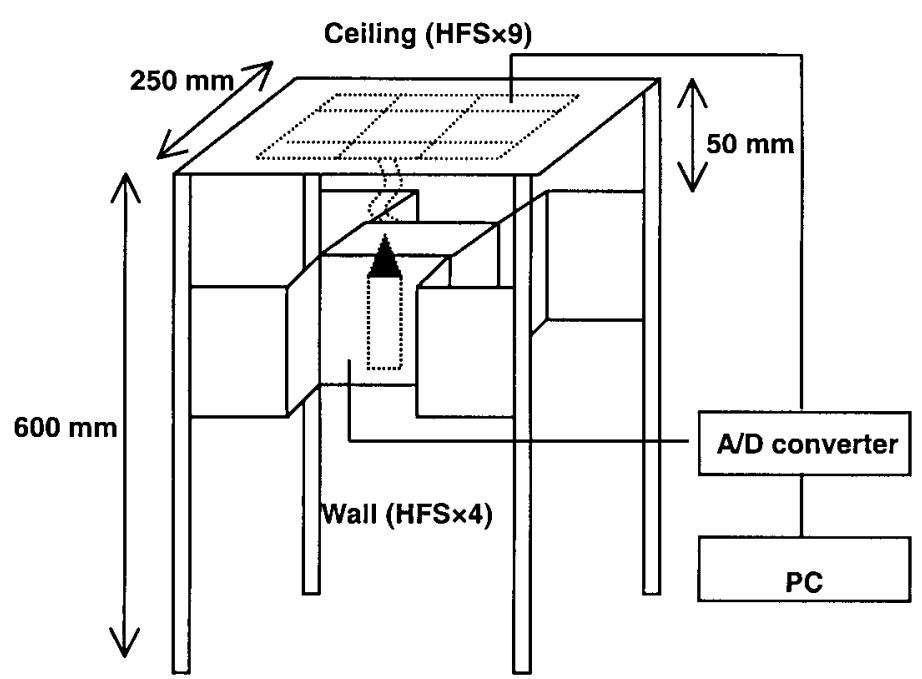

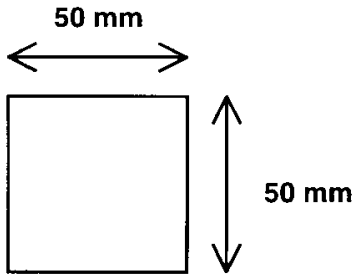

Heat flux sensor

Figure 2.

Schematic diagram of the experimental apparatus for measuring the emitted heat of a burning cigarette

Table 2.

Radiation heat from the top of the cigarette

\begin{tabular}{l|c|c}
\hline Cig. & $\begin{array}{c}\text { Top radiation heat } \\
(\mathrm{W})\end{array}$ & $\begin{array}{c}\text { Ratio to total heat emission } \\
\text { of the ceiling (\%) }\end{array}$ \\
\hline A & 0.055 & 1.5 \\
B & 0.065 & 1.8 \\
\hline
\end{tabular}

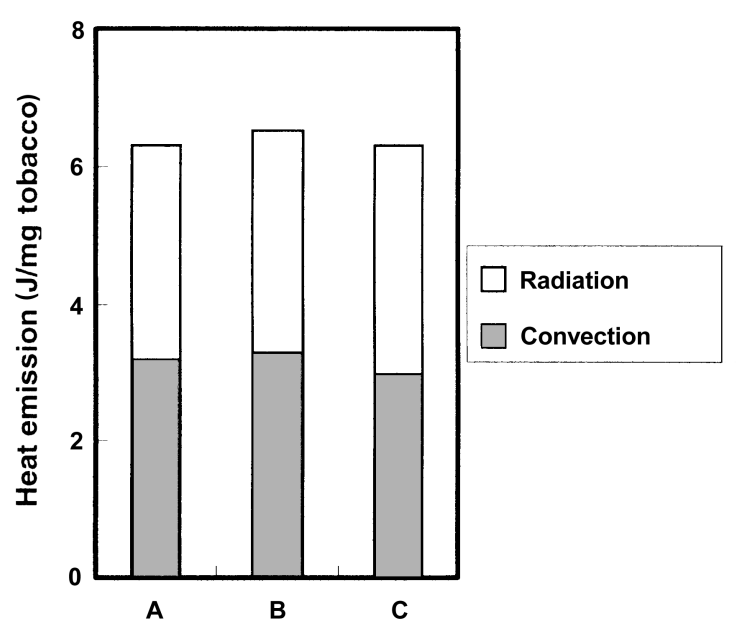

Figure 3.

Heat emission with static burn rate changed by cigarette paper variations

platinum-rhodium thermocouple of $0.05 \mathrm{~mm}$ diameter and found to be room temperature. This confirmed that the wall of the equipment detected only the radiated heat. The temperature of the top was measured with an infrared thermometer equipped with a $0.05-\mathrm{mm}$ diameter optical fiber. The radiation heat was calculated from the top temperature assuming that the radiation emissivity is 1. Table 2 shows the radiation heat from the top during burning of cigarettes A and B. A very small portion of the total heat emitted to the ceiling sensors was measured as radiated heat. The gas temperature at the edge of the ceiling was also measured to be at room temperature. Hence, the ceiling sensor detects only the total convected heat.

Figure 3 shows the net heat emitted from cigarettes with various smoldering burn rates. The radiation heat released from the surface of a cigarette is about $3.3 \mathrm{~J} / \mathrm{mg}$. The convection heat is about $3.2 \mathrm{~J} / \mathrm{mg}$. The ratio of radiation heat to convection heat is about 1 . The ratio varied little with a change of the smoldering burn rate.

In addition to the change in cigarette paper, we measured the heat emission for cigarettes with various tobacco densities. Figure 4 shows the heat emission along with changing tobacco density. The same results were obtained as in the cigarette paper study. The ratio of radiation heat to convection heat is about 1 and varied little with the change of smoldering burn rate. The heat emission per unit weight of tobacco shreds of a burning cigarette seemed to be independent of the burning rate.

\section{HEAT FLUX}

The local heat flux from a burning cigarette surface was measured with a heat flux gauge (Vatell Corporation). Figure 5 shows a schematic diagram of the experimental apparatus. The heat flux gauge can measure the total amount of heat flux absorbed through a 1-mm diameter gauge. The heat flux from a cigarette surface at each point was estimated during static burning. Figure 6 shows the distribution of heat flux from the cigarette surface along the longitudinal axis. The heat flux distribution varied among sample cigarettes. The length of the 


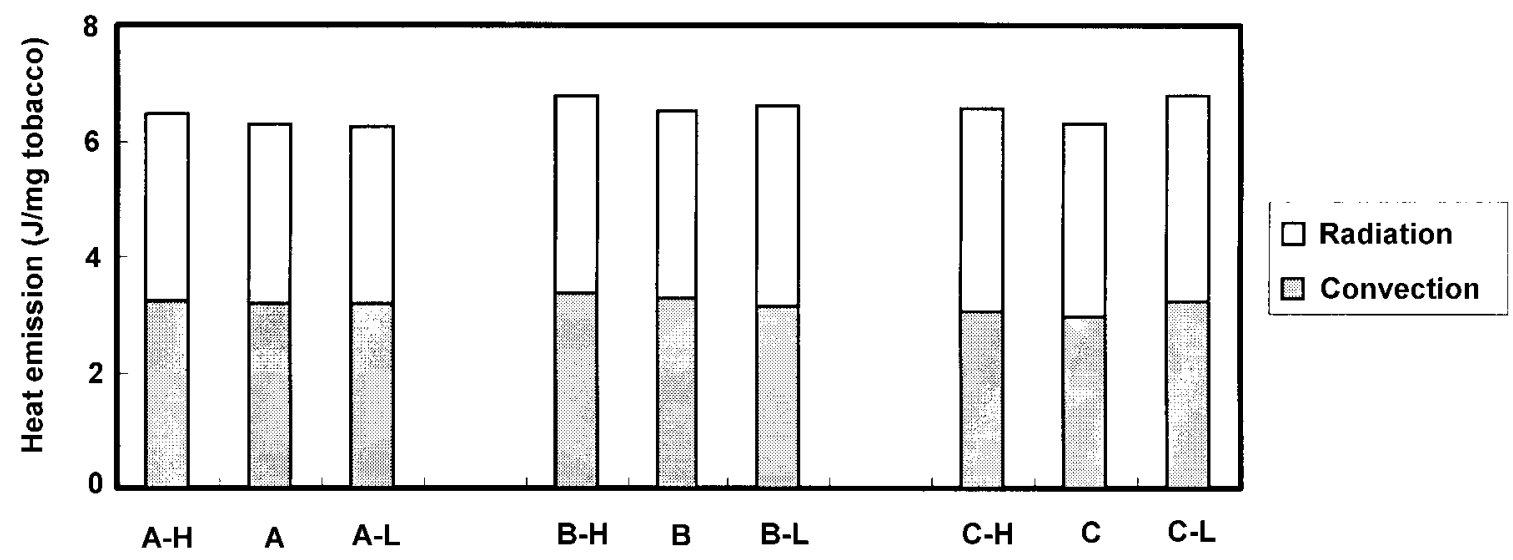

Figure 4.

Heat emission with static burn rate changed by tobacco density variations

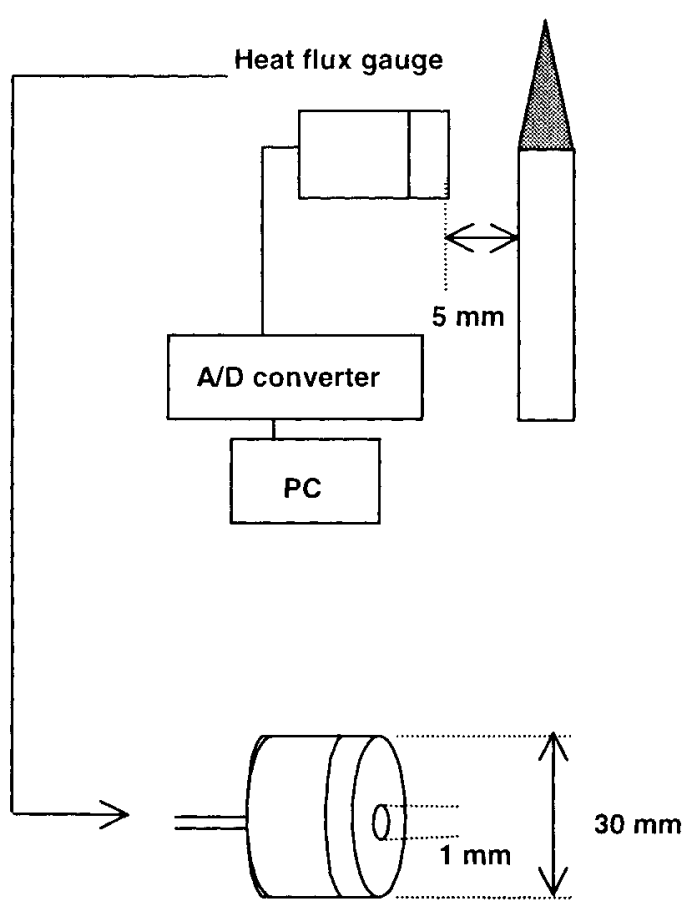

Figure 5.

Schematic diagram of the heat flux gauge for measurement of local heat flux

heat emitting area seems to be proportional to the static burn rate. The heat flux distribution near the char line differs slightly.

\section{DISCUSSION}

Static cigarette burning is an incomplete combustion which releases combustible gases and particles in addition to carbon dioxide and water. The net heat generated as well as the ratio of incomplete combustion to complete combustion are independent of the static burn rate.

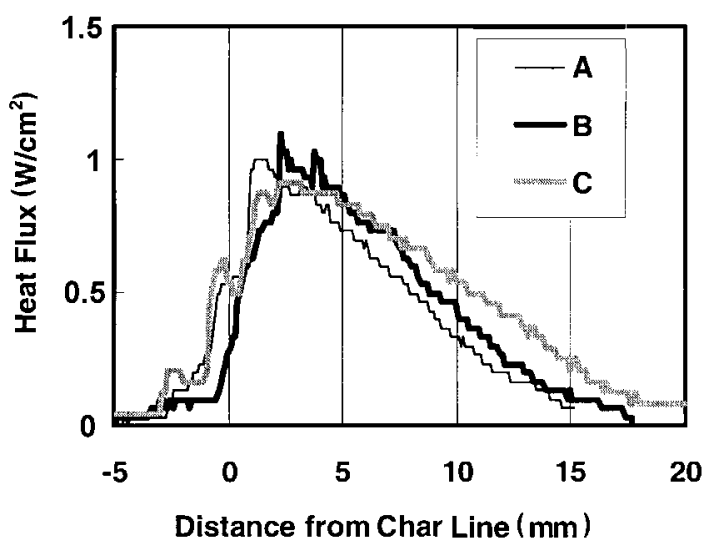

Figure 6.

Heat flux from the surface of the burning cigarette

The mass burn rate of a cigarette changes with different cigarette papers even though the tobacco bed inside the cigarette rod is the same. However, the net heat generated amounted constantly to about half of the complete combustion heat. It is thought that efficiency of heat generation is not a factor that affected cigarette static burn rate. As for heat generation, incomplete combustion of a cigarette was characterized by the release of combustible gases, such as hydrocarbons.

The net heat emitted is independent of the static burn rate. The heat emitted by radiation is $50 \%$ of the total heat emitted from the burning cigarette, and as well is independent of the static burn rate. It is well known in the literature that with a higher static burn rate the cigarette has a longer char cone $(4,5)$. Figures 3 and 4 indicate that the shape of the char cone does not affect the net radiation heat emission. As shown in Figure 4, changes in tobacco density did not influence the net heat emitted by radiation and convection. It is assumed that emitted heat passes mostly through the ash because the major part of heat generation occurs nearby the surface of the char cone.

The surface heat flux at a distance of $4 \mathrm{~mm}$ or more from 
the char line increased with an increase in the static burn rate. This confirms that a high burn rate leads to a long char cone, which in turn generates the larger heat emission. On the other hand, similar heat flux distribution among the cigarettes $\mathrm{A}, \mathrm{B}$ and $\mathrm{C}$ could be seen near the char line. Those cigarettes also had the highest heat flux of about $1 \mathrm{~W} / \mathrm{cm}^{2}$ at approximately $2 \mathrm{~mm}$ from the char line. These results indicated that changes in static burn rate caused little difference in the heat emission near the char line.

\section{CONCLUSIONS}

We investigated the net heat generated and the heat emission from a static burning cigarette. The net heat generated is approximately $7.8 \mathrm{~J} / \mathrm{mg}$, and is independent of the static burn rate. The radiation heat released from the surface of a burning cigarette is about $3.3 \mathrm{~J} / \mathrm{mg}$, and is the same as the heat emitted by convection. These values are independent of changes in the static burn rate by cigarette paper or tobacco density. Heat flux distribution of the cigarette surface varied with the static burn rate. The length of the heat emitting area seemed to be proportional to the static burn rate. There was only a small difference in the heat flux near the char line if the static burn rate changed.

\section{REFERENCES}

1. Rice, R.L., Perrier, R.S. and Runeckles, V.C.: A weight loss technique for determining rate of static burn; Tob Sci. 14 (1970) 73-175.

2. Miura. K.: Oxygen diffusion through cigarette paper; Beitr. Tabakforsch. 19 (2000) 205-208.

3. Gugan, K.: Natural smolder in cigarettes; Combustion and Flame 10 (1966) 161-164.

4. Muramatsu, M.: Studies on the transport phenomena in naturally smoldering cigarettes; Sci. Papers Cen. Res. Inst. Japan Tobacco and Salt Public Corp. 123 (1981) 9-78.

5. Waymack, B.E., Kellog, D.S., McRae, D.D. and Dwyer, R.W.: Watts in a cigarette: Thermophysical properties of smoldering cigarettes; Tob. Sci. 41 (1997) 74-81.

Address for correspondence:

Tobacco Science Research Center

Japan Tobacco Inc.

6-2, Umegaoka, Aoba-ku

Yokohama, Kanagawa 227-8512

JAPAN 